\title{
ANALYSIS OF PUBLIC TRANSPORT USERS' SATISFACTION USING QUALITY FUNCTION DEPLOYMENT: BELGRADE CASE STUDY
}

\author{
Stanko BAJČETIĆ, Slaven TICA, Predrag ŽIVANOVIĆ, \\ Branko MILOVANOVIĆ ${ }^{*}$, Andrea ĐOROJEVIĆ \\ Faculty of Transport and Traffic Engineering, University of Belgrade, Serbia \\ Received 13 June 2016; revised 5 September 2016; accepted 3 December 2016
}

\begin{abstract}
This paper presents a case study using Quality Function Deployment (QFD) method to identify urban public transport users' needs and requests and to improve service quality in urban public passenger transport in Belgrade. In order to determine users' satisfaction, a direct interview - survey a sample of 15000 of urban public passenger transport system users, according to the defined questionnaire has been performed. Results of these interviews are used as input in the first stage of QFD method. An overall unit of eight features and a total of 48 sub-features were defined, which describes all aspects of quality of system and services in urban public passenger transport. The results show that for maximizing effects of quality of service improvement and satisfying customers' requirements, the public transport service providers and managers in Belgrade should focus primarily on the service reliability and vehicle elements. The two most important quality of service sub-features in urban public passenger transport system in Belgrade based on frequency of statements of users was regularity with 4896 (32.64\%) and vehicle comfort (not crowded vehicles) with 3446 (22.97\%) statements. Based on the service features analysis within the house of quality, it was defined that the biggest influence is generated through system functioning parameters (reliability): frequency with relative importance $22.0 \%$, staff (drivers) with relative importance $14.0 \%$ and headway with relative importance $13.0 \%$. Based on absolute importance the greatest importance should be assigned to vehicle frequency - rank 1, staff (drivers) - rank 2 and headway - rank 3.
\end{abstract}

Keywords: urban public passenger transport, users' satisfaction, transport service, quality function deployment, house of quality.

\section{Introduction}

Determination of user's satisfaction in order to improve quality of service presents procedures of system-based and system-managed process of collection, processing, selection, analysis and presentation of selected data (Tica 2011). In line with new approach to quality of service in transport and understanding quality as a measure to achieve users' expectations, new approach in transport services production emerged known as 'customer servicing. The process of 'servicing' customers comprises all key system stakeholders, starting from local policy, operators, and users to industry, which provides logistics support to transport service production. The customer servicing skill is a pre-condition for creation of added values without which service development process is not possible to image. A user becomes the main party in the servicing process and the final judge when it comes to service quality. In urban public passenger transport, service quality is an aspect in- fluencing travel user choices, defined as customer perception of how well a service meets or exceeds expectations (Parasuraman et al. 1988). Therefore, the measurement of service quality and users' satisfaction is an imperative of modern market business and a challenging research theme for both service providers and regulatory agencies (Hensher et al. 2003).

Due to a number of specific issues in the process of providing and using transport services, measuring satisfaction level is a complex process. Hu and Jen (2006), Beirão and Cabral (2007), Eboli and Mazzulla (2007), Stradling et al. (2007), Tyrinopoulos and Antoniou (2008), Filipović et al. (2009) evaluated service quality in various modes of passenger transport.

Different approaches are present in the quality of service and users' satisfaction research. Many authors measured service quality through service features and ranking

${ }^{*}$ Corresponding author. E-mail: b.milovanovic@sf.bg.ac.rs 
of their importance. Numerous authors (Parasuraman et al. 1988; Filipović et al. 2009; Eboli, Mazzulla 2010; Cirillo et al. 2011) found that reliability is one of the most important features in service quality. In many studies two service quality features, frequency (accessibility in time) and cleanliness (station and vehicle), have been found to affect service quality (Hensher et al. 2003; Tyrinopoulos, Antoniou 2008; Cirillo et al. 2011; Eboli, Mazzulla 2012). On the other side, Agarwal (2008) found that employee behaviour (service feature: staff) has a maximum effect on satisfaction level of customers on transportation services. Friman and Edvardsson (2003) identified the positive effects of employee-related issues on passengers' perceived quality. It is obvious that there is no 'ultimate' quality feature important for all users, rather their expectations depends on various factors and importance lists differ from system to system.

There are many examples of combining the service quality and Quality Function Deployment (QFD) in different areas. Lim et al. (1999) adopted service quality to health care performance measurement in Singapore and used the empirical findings as an input for QFD in the process of designing services based on customer expectations for hospitals. Franceschini and Rafele (2000) compared traditional logistics service quality attributes with service dimensions defined in SERVQUAL for logistics services in manufacturing. Apparao and Birru (2014) applied QFD for enhancement of customer satisfaction in Indore metro-taxi service. They conclude that the adapted three-phased, service-based QFD methodology proved to be an effective tool for translating the customer requirements into 'what to carry out'. Rao and Thakar (2013) discussed in their paper 'how to gain the passenger satisfaction' of the most popular type of public transport system, namely the metropolitan bus service, through QFD. With the results obtained from final stage of QFD, authors conclude that for promoting service quality improvement and satisfying customer's requirements, the bus service has to focus more on 'operations management' i.e., greater emphasis is on 'bus schedule assignment' followed by 'staff duty assignment' and 'strategic planning.' Kurtulmuşoğlu et al. (2016) used fuzzy QFD as a tool to help designers and decision makers in improving service quality in the passenger transport industry. Authors identified that the most important quality element was the 'lost personal belongings services', while the least important was the 'visual characteristics of the ticketing area'. Pakdil and Kurtulmuşoğlu (2014) developed a QFD methodology that combines the passengers' perceptions and transport service providers' technical knowledge to improve quality of the highway passenger transport services. Authors found that the most important factors in satisfying consumer voice are 'employees' empathetic approach toward customers', 'technical specifications of buses', 'error-free services' and 'competent employees'. Limitation of this study was sample size (285 respondents) from just one focus group (university students). Maritan (2015) inves- tigate possibility of QFD implementation when planning a new bus service. QFD is applied to a service company (Citymove) working in a monopoly position. Seventy five characteristics of the Citymove service have been identified and they were arranged in a two level structure. The most important features for Citymove were: reducing overcrowded buses, improving regular times, increasing punctuality, increasing the security network and increasing integration with other travel documents. There is also an application of QFD in service quality assessment of Asian liner shipping firms (Huang et al. 2015).

This paper presents a case study using QFD method to identify urban public transport users' needs and requests and to improve service quality in urban public passenger transport in Belgrade. The paper reports how QFD could be implemented for improving the quality of service in urban public transport.

Basic research objectives are:

- identification of users' needs and requests regarding the quality of service in urban public transport;

- ranking of quality features importance for users (expected quality of service);

- measuring the users' satisfaction level (perceived quality of service);

- comparative analysis of changes in users' expectations and satisfaction with the quality of service in public transport vs. individual transport (system competitive benchmarking).

The structure of the paper is as follows: first, brief description of QFD method is given, followed by presentation of basic facts about urban public passenger transport system in Belgrade, Serbia. In the next section procedure of the QFD method first stage implementation is described, starting from defining the features and subfeatures of quality of service and their importance in urban public passenger transport system in Belgrade. This analysis resulted in ten most important transport quality of service features, ordered by their relative and absolute importance for urban public passenger transport system users in Belgrade within the house of quality. We finish with some concluding comments.

\section{QFD method overview}

In order to provide quality transport service in limited time and specific market environment, it is essential that transport service planners, managers and providers have specific models, methods and techniques. Numerous authors (Feigenbaum 1988; Dale, Lascelles 1990; Crosby 1991; Greene 1993; Ivancevich et al. 1996; Stoiljković et al. 1996; Jayaram et al. 1997; Spasojević 1999; Heleta 2010) dealt with the classification of quality management methods and techniques. Each of the existing methods and techniques has both advantages and disadvantages, which define the field of its optimal implementation. However, current research practice lacks with models and techniques, which treat the problem of quality and transport 
service users' satisfaction in the overall and systematic way. The main reason for that is the nature of transport service itself, i.e. its multi-parameter character:

- subject of work - a passenger does not belong to a provider of transport service. Passenger is at the same time both the subject of work and user of service;

- multi-parameter transport service feature - apart from scope and quality, space and time are important transport service parameters compared to other products and services;

- simultaneity of production and service consumption in time and space - transport service must be provided, at the place where and at the moment of time when the request was sent, in scope and quality as required;

- reliability of functioning in the sense of service scope and quality of transport systems is provided through capacity reservation - vehicles, not like in the case of other production-technological systems through reserving products (services);

- final quality control is conducted simultaneously with 'service consumption'.

Therefore, general models and methods available in literature are not possible to use in their original form but it is necessary to modify and adapt them to a specific problem. Method for service quality planning and projecting - QFD was developed in '70 last century in Japan and it is used today in many fields worldwide. Mizuno and Akao (1994) defines QFD as 'a method for developing quality in projecting with an objective to satisfy consumer and then to transfer users' requests into projecting objectives and main points of quality provision which will be used during production. Some authors refer to QFD method as 'planning of quality directed to users' requests' (Radivojević et al. 2007). This method defines service features completion and critical parts of the service and in the process of service implementation. It defines also the procedures for managing these critical issues. Thus, the final objective is achieved, i.e. reaching the exact quality level, which complies with users' requests (Juran 2003; Juran, Gryna 1988).

QFD method is mainly described through four stages, which are implemented within four so-called 'houses of quality' (Figure 1). Houses of quality represent matrices formed in a way that they have the same basic look in every stage (Masing 1988). House of quality consists of six major steps (Chan, Wu 1998; Wu et al. 2005; Wu 2006; Shieh, Wu 2009): customer requirements (WHATs), planning matrix, technical measures (HOWs), relationship matrix between WHATs and HOWs, technical correlation matrix and technical matrix. At the entrance to the 'house of quality', in the left column, there is always a question: 'what is required?' and at the exit there is always the answer: 'how to comply with requests?' QFD presents system service planning process, which starts with the Stage I where users' wishes, needs and expectations are defined based on the research results. Afterwards, within

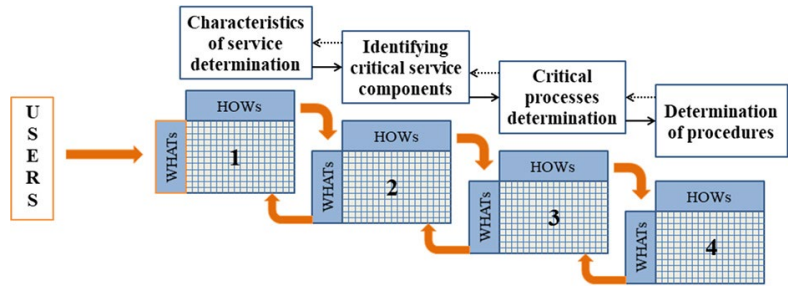

Figure 1. Stages of QFD method (method implementation on service)

the Stage II, critical service components, which require more detailed researches are defined. Stage III comprises defining of production process critical parameters i.e. service providing, and finally, in Stage IV, service quality control processes, i.e. instructions and measures to be taken for implementation of the process itself with certainty, are defined.

Users' attitudes are the basis for defining the most important service features, which have the biggest effect on the level of quality of service offered to users. Therefore, for further research analysis, the most critical part of the process is Stage I. Results of this stage represent key users' requests and their importance as well as key service features essential for required quality production. This lead to users' satisfaction and market advantages achievement. The procedure of Stage I within defining research methodology was implemented through completion of the first 'house of quality' (Figure 1).

\section{Implementation of QFD method in urban public passenger transport system in Belgrade}

\subsection{Urban public passenger transport system in Belgrade}

The urban public passenger transport system in Belgrade is one of the greatest transport systems in South-Eastern Europe and it consists of four subsystems: bus, trolleybus, tramway and suburban rail subsystems.

The line network consists of more than 364 regular lines in daily traffic, with total length of 8500 kilometres:

- tram subsystem, with 12 lines and total length of 127.3 kilometres;

- trolleybus subsystem, with 8 lines and total length of 58.1 kilometres;

- urban bus subsystem, with 119 lines and total length of 1800.4 kilometres;

- suburban bus subsystem, with 225 lines and total length of 6471.3 kilometres;

- urban rail subsystem, with 1 line and total length of 23.6 kilometres.

The total number of passengers transported by the urban public passenger transport system in Belgrade is 2539773 passengers a day and the largest modal share has the bus subsystem, which transports 2118021 passengers a day (83.39\%), followed by the tram subsystem with 244199 transported passengers a day $(9.61 \%)$ and the trolleybus subsystem with 150355 transported passengers 
a day (5.92\%). Annual number of passengers transported by Belgrade's urban public passenger transport system is around 685 million.

The total inventory number of vehicles in urban public passenger transport system in Belgrade is 1840: 1349 buses, 232 trams, 126 trolleybuses and 7 trains. Average fleet age is 10.17 years (from 7.77 for buses to 27.45 for trams). All vehicles are equipped with ventilation and heating system. Vehicles which operate on trolleybus line route 22 and tramline routes 7,12 and 13 have automated ramps and are fully accessible for disable persons. Urban public passenger transport system in Belgrade has modern electronic vehicle management system and e-ticketing fare collection (contactless smart cards) system. Transport network includes four zones - inner city center, wider city area and suburban areas. Four card types exist: personalized, non-personalized, paper, 'e-wallet' card, which can store several ticket types - a 90-minute ticket, 1, 3 or 5 -day tickets and a group ticket. Ticket prices range from 0.71 EUR for a 90-minute ticket, 2.24 EUR for 1 day ticket to 39.92 EUR for a monthly ticket for employees for all four zones.

\subsection{Research methodology}

The method used for data collection from users in order to determine their requests was a direct interview - survey of urban public passenger transport system users, according to the defined questionnaire. The research sample comprised 15000 participants.

Research was carried out in a continuous period of 12 hours, from 7:00 to 19:00, which included the most significant periods of operation of the system (two peak and two off-peak time periods). The study was conducted during the four working days (GSP 'Beograd' 2014).

The representativeness of the sample in space is provided based on research on the characteristic public transport stops that cover all key corridors of passenger flows and public transport line routes. Selection of stops, which some are common to the various subsystems (17 stops for the urban and 4 stops for the suburban lines), included a high percentage of the total network line coverage $(82.95 \%$ of line routes).

The research methodology comprised that users should opt for, in their opinion, the most important quality service features in the system and rank their importance. The importance of features and sub-features is defined with the frequency of statements i.e. percentage of users who opted for every of the features (sub-features) of quality and in line with the average ranking of each quality feature (sub-feature) importance.

\subsection{Procedure of the QFD method first stage implementation}

The process of determining the service quality in urban public passenger transport system in Belgrade comprised nine interconnected steps through which, based on users' requests, final solutions related to structure and quality of transport service were defined.

Step 1: Users' Request Identification. According to the results of research, in total number of respondents $42.6 \%$ were full-time employees, $20.9 \%$ were students, $13.6 \%$ were senior citizen, $11.1 \%$ were unemployed and $10.3 \%$ were pupils. Remaining respondents declared themselves as occasionally employed (1.5\%). The gender structure has shown that a greater number of females (52.8\%) used urban public passenger transport than males (47.2\%). It is interesting to note that $80.9 \%$ of customers use urban public passenger transport every day.

Users' requests are the basic entry data of QFD process and thus the basis for quality matrix set up. Understanding exactly what customers expect is the most crucial step in defining and delivering high-quality service (Zeithaml et al. 1996). The first quality of service researches in urban public passenger transport system in Belgrade were conducted in 1997 (Filipović 1996; Filipović, Stanković 1996) and they were repeated in 2001 (Filipović et al. 2002) on the sample of almost 50000 participants which is more than some $3 \%$ of total daily number of transported passengers. Since 2005 (Filipović et al. 2006; Filipović et al. 2007; Filipović et al. 2008), researches of quality service parameters in urban public passenger transport system in Belgrade have been conducted once a year, comparative analysis of these research data is given by Filipović et al. (2009). Similar researches in urban public transport system in Belgrade were carried out in 2013 (Grujičić et al. 2014). In all these researches, an overall set of eight features and a total of 48 sub-features were used, which describe all aspects of quality of system and services in urban public passenger transport (Table 1).

Figure 2 presents ten most important sub-features of urban public passenger transport quality of service in Belgrade based on questioned users' statements frequency.

Step 2: Defining Importance of Users' Requests. Monitoring of trends in expected and perceived quality of service in urban public passenger transport system in Belgrade, revealed that system users react positively on every improvement within some quality of service features and sub features, but not all improvements resulted in equal increase in users' satisfaction level.

For a selected quality sub-features, users were providing answers with respect to its importance ranking. Based on these users' statements an average importance ranking was calculated for every sub-feature. The average rank for each feature (sub-feature) of quality is obtained as quotient of the sum of multiplied frequency of occurrence by ranks with correspondent rank and the total frequency of occurrence of that feature. The lower the average rank the more important feature is for users. Figure 3 presents quality of service sub-features in urban public passenger transport system in Belgrade based on their average importance ranking.

Step 3: Comparison with Competition. The objective of this step is to provide better quality of service with respect to competition with which comparison was con- 
Table 1. Features and sub-features of the quality of service of urban public passenger transport system in Belgrade (Filipović et al. 2009)

\begin{tabular}{|c|c|c|c|}
\hline \multicolumn{4}{|c|}{ Easy to use } \\
\hline Station comfort & Vehicle comfort & Tickets and pricing & Information \\
\hline $\begin{array}{l}\text { protection from rain, } \\
\text { sun and wind }\end{array}$ & not crowded vehicles & easy ticket purchase & $\begin{array}{l}\text { information on urban public } \\
\text { passenger transport in advance }\end{array}$ \\
\hline station cleanliness & vehicle cleanliness & large assortment of tickets & $\begin{array}{l}\text { information on urban public } \\
\text { passenger transport at stations } \\
\text { and in vehicles }\end{array}$ \\
\hline $\begin{array}{l}\text { station ventilation and } \\
\text { heating }\end{array}$ & ventilation and heating & prepaid transfer tickets & $\begin{array}{l}\text { information on urban public } \\
\text { passenger transport at different } \\
\text { places in town }\end{array}$ \\
\hline sitting possibility & sitting possibility & discount possibility & information on lines \\
\hline station aesthetics & vehicle aesthetics & ride price level & information on timetable \\
\hline lighting & adapted grips & price-quality ratio & information on tickets and prices \\
\hline $\begin{array}{l}\text { easy boarding from } \\
\text { platform }\end{array}$ & ride without sudden braking & & \\
\hline \multirow{2}{*}{$\begin{array}{l}\text { passenger's safety at } \\
\text { station }\end{array}$} & music in vehicles & & \\
\hline & safety in vehicle & & \\
\hline \multicolumn{2}{|c|}{ Service availability } & Service stability & Organizational support \\
\hline Accessibility in time & Spatial Accessibility & Transport reliability & Staff \\
\hline a lot of departures & $\begin{array}{l}\text { urban public passenger transport } \\
\text { station vicinity }\end{array}$ & regularity & neat staff \\
\hline service continuity & line covering & punctuality & identifying uniforms wearing \\
\hline $\begin{array}{l}\text { early morning and late } \\
\text { evening departures }\end{array}$ & \multirow{2}{*}{ easy transfers } & no other disturbances & culture and amiability \\
\hline $\begin{array}{l}\text { boarding on the first } \\
\text { vehicle }\end{array}$ & & expected travel time achieved & competency \\
\hline
\end{tabular}

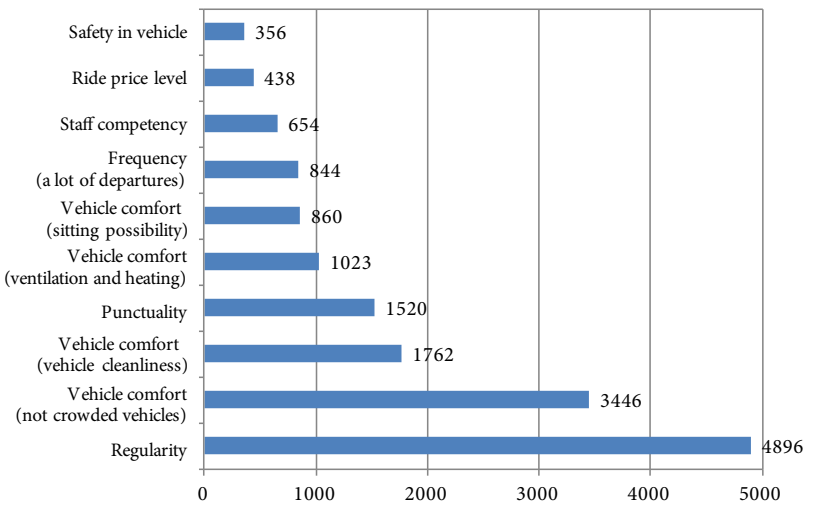

Figure 2. Ten most important sub-features of urban public passenger transport quality of service in Belgrade based on questioned users' statements frequency

ducted. For comparative analysis, individual transport (by passenger cars (PrT)) was selected, primarily due to increase in motorization degree and all negative consequences emerging from exaggerated usage of passenger vehicles. Comparison with competitive transport mode from users' point of view was shown through benchmarking method. A five-grade Likert scale (from 1-insufficient to 5-excellent) is used for comparison.

The analysis shows that only request 'transport price' was ranked worse with individual compared to

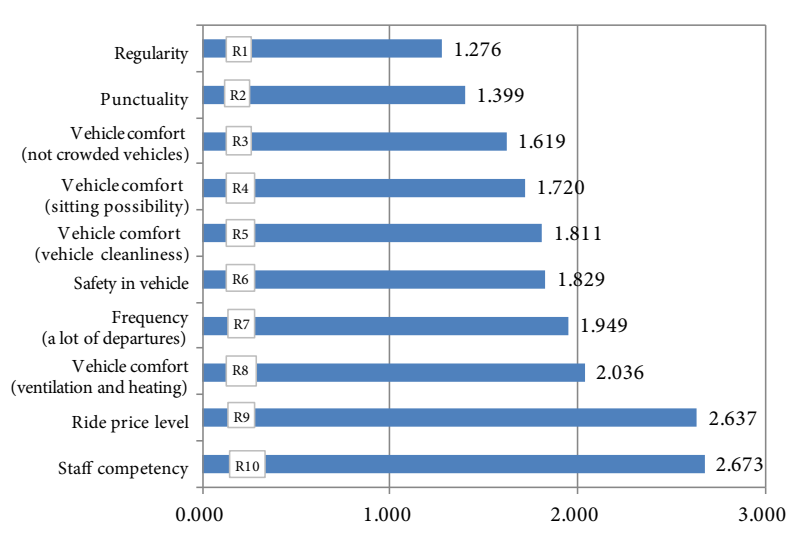

Figure 3. Quality of service sub-features in urban public passenger transport system in Belgrade based on their average importance ranking

urban public passenger transport system, i.e. lower costs are seen as the only advantage of urban public passenger transport compared to passenger car. Vehicle comfort in public transport was particularly badly graded which is not a surprise bearing on mind an issue of collectively related to public transport. Moreover, modal share of public transport in Belgrade is 52\%, which results in possibility of overcrowding in peak hours. The other reason can be found in relatively old vehicle fleet. It is interesting that these data are in line with all previous researches of esti- 
mated quality of service, which showed that vehicle comfort is a quality service feature where passengers in urban public passenger transport are the least satisfied (Filipović et al. 2009).

Step 4: Service Features Definition. The next step in methodology is defining service features, which affect fulfilment of each delivered request. From the wide range of transport offer elements and other elements of provided transport service, so-called system Key Performance Indicators (KPI), i.e. features, which qualitatively describe users requests were selected (Tica 2011). The first 6 selected features refer to dynamic elements of transport network (headway, frequency, turnover speed) and features of the basic resource - vehicle (reliability - technical regularity, equipment and interior and capacity). The next 6 features were selected from the group of static elements of transport network and indicators of spatial accessibility (number of stops (on route), stop environment, stop equipment, stop distance, transport network density, pedestrian availability coefficient). The importance of tariff policy and pricing policy was shown through 3 parameters (tickets price, assortment of tickets, tariff policy (benefited categories)), two features refer to staff (drivers' absence, staff training) in the system and the last feature is information level of users.

Every feature fits into clearly defined functional request, which is formed based on users' requests. With the improvement of these features, better service, better performance are achieved and functional requests are fulfilled and thus user gets what he wants as well (expected quality of service).

For instance, if users require shorter travel time from initial to final destination, headway, turnover speed and bus stop are set as factors influencing quality planning. Passengers want as many bus stops as possible so that they would decrease time of walking from initial to targeted travel destination (bigger number of bus stops requires bigger number of vehicle halts which increases travel time; every halt of a vehicle at bus stops results in loss of time and cost increase for one number of users). Fleet techni$\mathrm{cal}$ readiness as well as organization and management of system functioning have crucial role in service reliability.

Step 5: Correlations of Users' Requests and Service Features. Through the main matrix of house of quality, correlation between users' requests and elements of the service design were set. The relation intensity was shown with different symbols, atomicity 1-3-9 (grade 1 stands for weak connection, grade 3 middle and grade 9 strong connections). In literature, models of interdependence of all mentioned indicators were developed (Tica 2001), which were taken as the basis in correlation intensity defining. One service features can influence more users' request with different correlation intensity just as one user request can be influenced by a number of service features. The Figure 4 shows interdependence of vehicle comfort expressed though comfort coefficient and total vehicle capacity. If the number of transported passengers and the passengers' exchange coefficient are set as constant values

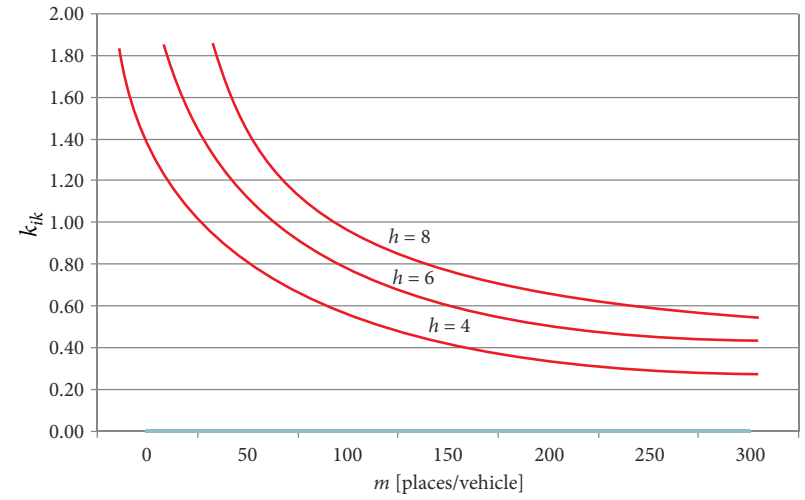

Figure 4. Comfort change $\left(k_{i k}\right)$ as the function of vehicle capacity $(m)$ for different values of headways $(h)$ and for number of transported passengers $(P=$ const $)$ and passengers' change coefficient $(\eta=$ const) (Tica 2001)

(e.g. $P=700$ and $\eta=1.45$ ), the diagram of comfort change as the function of vehicle capacity for different values of headways (e.g. value of 4, 6 and 8 minutes) is shown at Figure 4.

The Figure 4 shows that for bigger vehicle capacity, comfort capacity is higher for different values of headways, i.e. for bigger vehicle capacity, passengers have bigger comfort in a vehicle.

The analysis showed that turnover speed and travel time have high correlation; frequency relates to stability, punctuality and regularity, frequency; staff (drivers) strongly influences system reliability as well as safety and security; while correlation between travel time and number of stops at a route is low. Stop environment has weak effect on safety and security. Table 2 provides an overall matrix of interdependence of users' requests and service features.

Step 6: Correlations between Service Features. Within the house roof there is a matrix, which points out at potential conflict objectives between two features. Interdependence was shown with suitable symbols and the correlation itself can be extremely positive, positive, negative and extremely negative. Previous researches on the interdependence between transport services features were used in this analysis as well (Prasad 1998; Wu, Shieh 2010; Duru et al. 2013). It was shown that headway and transport speed have strong degree of correlation, i.e. these two features depend on each other. Moreover, informing passengers and staff education are also strongly correlated as well as stop distance on transport network density.

Step 7: Quality Plan. This step defines quality plan, which also comprises criteria of users' importance, which is used in strategic management of urban public passenger transport system. The plan comprises: criteria of users importance; target value for development of system image at the market, though grading on the scale from 1 to 5 , where 1 stands for changes, 3 for development, 5 for service better than competitor's; sale factor, assigning 1 if a service has negative sale effect and 2 if service has positive sale effect. 
Table 2. List of users' requests and service features

\begin{tabular}{|c|c|}
\hline Users' requests & Service features \\
\hline Travel time & $\begin{array}{l}\text { - headway; } \\
\text { - turnover speed; } \\
\text { - stop }\end{array}$ \\
\hline Reliability & $\begin{array}{l}\text { - vehicle (reliability, technical } \\
\text { regularity); } \\
\text { - staff (drivers' absence) }\end{array}$ \\
\hline Stability & $\begin{array}{l}\text { - headway; } \\
\text { - frequency }\end{array}$ \\
\hline Punctuality and regularity & $\begin{array}{l}\text { - headway; } \\
\text { - frequency }\end{array}$ \\
\hline Safety and security & $\begin{array}{l}\text { - vehicle (equipment } \\
\text { and interior); } \\
\text { - stop environment; } \\
\text { - staff (driver) }\end{array}$ \\
\hline $\begin{array}{l}\text { Vehicle comfort } \\
\text { (not crowded vehicles) }\end{array}$ & $\begin{array}{l}\text { - vehicle capacity; } \\
\text { - headway }\end{array}$ \\
\hline $\begin{array}{l}\text { Accessibility in time } \\
\text { (a lot of departures) }\end{array}$ & - frequency \\
\hline $\begin{array}{l}\text { Spatial accessibility } \\
\text { (station vicinity) }\end{array}$ & $\begin{array}{l}\text { - stop distance; } \\
\text { - transport network density; } \\
\text { - stop catchment area }\end{array}$ \\
\hline $\begin{array}{l}\text { Vehicle comfort } \\
\text { (ventilation and heating) }\end{array}$ & $\begin{array}{l}\text { - vehicle (equipment and } \\
\text { interior) }\end{array}$ \\
\hline Transport price & $\begin{array}{l}\text { - ticket prices; } \\
\text { - assortment of tickets; } \\
\text { - tariff policy (benefited } \\
\text { categories) }\end{array}$ \\
\hline Station comfort & $\begin{array}{l}\text { - stop equipment; } \\
\text { - users' information level }\end{array}$ \\
\hline Staff competency & - staff training \\
\hline
\end{tabular}

In a specific case of urban public passenger transport system in Belgrade, these parameters values are as follows:

- target value ranks 1 for majority of criterion, i.e. there is a need for changes, while three features (safety and security, comfort at stops and staff competence) should be improved (target value 3 ). The feature of price and service where target service value is better than competitive transport means individual transport;

- negative sale effect (sale factor with value 1) is seen at vehicle comfort feature and at stops as well as staff features while other service elements were assigned positive value of this effect, i.e. sale factor has value 2 .

In order to define absolute value of importance for every service criteria (quality sub-feature) for the users, the following formula has been used:

$$
A_{v}=Z_{k} \cdot K_{r} \cdot F_{p}
$$

where: $A_{v}$ - absolute value of importance; $Z_{k}$ - users' importance degree; $K_{r}$ - service feature; $F_{p}$ - sale factor.

Taking absolute value of importance into an account, the most important service sub-features are definitely transport price (50), safety and security (48), as well as punctuality and regularity (20).

Step 8: Service features analysis. In the pre-final step based on the analysis of the collected results, absolute importance of some features was defined, generated as an arithmetic sum of all products of users' importance and correlation degree of every service feature, in line with the following formula:

$$
A_{z, j}=\sum_{i=1}^{n} Z_{k, i} \cdot K_{r, i},
$$

where: $A_{z}$ - absolute importance of a feature; $Z_{k}$ - users' importance degree; $i$ - user request; $j$ - service feature; $n$ - number of selected users' requests.

Then, relative values were calculated as:

$$
R_{z, j}=\frac{A_{z, j}}{\sum_{j=1}^{m} A_{z, i}} \cdot 100[\%],
$$

where: $R_{z}$ - relative importance of a feature; $A_{z}$ - absolute importance of a feature; $i$ - user request; $j$ - service feature; $m$ - number of service features.

The analysis showed that for urban public passenger transport system in Belgrade, system operating parameters have the greatest effect (reliability): frequency with relative importance $22.0 \%$; staff (drivers) with relative importance $14.0 \%$; headway with relative importance $13.0 \%$. These are followed by the vehicle features: vehicle equipment with relative importance $8.7 \%$, vehicle capacity with $7.0 \%$ and vehicle reliability (technical regularity) with $6.0 \%$ (Figure 5).

Step 9: Service Features Importance Ranking. Based on absolute and relative importance, every service feature got its importance ranking. Within this step, importance of implementation of some service features were ranked through assigning value 1 for the most important solution and 10 for the least important solution. Ranking of features in line with importance is followed also by their absolute and relative importance so the greatest importance should be assigned to vehicle frequency - rank 1, staff (drivers) - rank 2; headway - rank 3. Vehicle equipment, optimal vehicle capacity and vehicle reliability (technical regularity), are ranked at positions 4, 5 and 6, respectively.

Focusing on these key features, quality of service can be developed and users' satisfaction level can increase. These features represent a step into the QFD method second stage.

\section{Conclusions}

The paper shows implementation of QFD method in the urban public passenger transport system. QFD method proved to be a useful and applicable tool in the analysis of importance of quality of service features for users of urban public passenger transport system in Belgrade. Correlation between users' requests and processes (activities) which influence service design was established. An extensive group of eight features and a total of 48 sub-features 


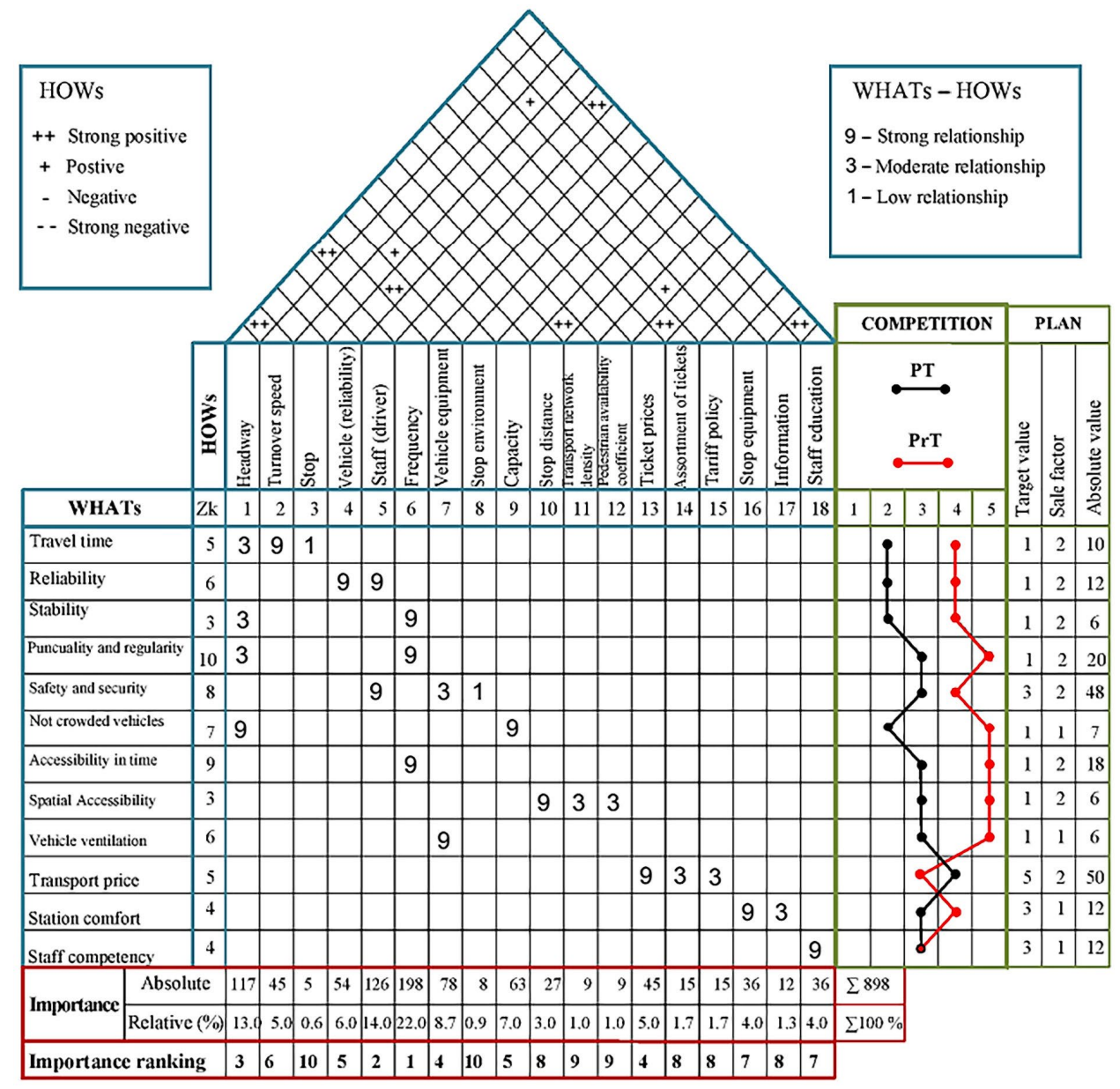

Figure 5. Implementation of house of quality in quality of service development in urban public transport passenger system in Belgrade

which describe all aspects of system quality and service in urban public passenger transport system were defined.

QFD enables not only the analysis of element of the urban public transport system, but also the comparative analysis with other transport modes. Constant increase in individual transport greatly influences urban public passenger transport and represents its real competition. Described methodology includes also a comparison with competition based on the users' requests.

Based on conducted researches on a sample of 15000 participants (method: direct interview) and implementation of the first stage of QFD method, according to basic research objectives defining in introduction of the paper, the following can be concluded:

- the biggest number of users (55.61\%) said they find two most important quality of service sub-features in urban public passenger transport system in Belgrade are regularity with 4896 of statements and vehicle comfort (not crowded vehicles) with 3446;

- regularity has also the highest average importance ranking $(R 1)$, followed by punctuality $(R 2)$, vehicle comfort (not crowded vehicles) $(R 3)$, vehicle comfort (sitting possibility) (R4) and others;

- based on the service features analysis within the house of quality, it was defined that the biggest influence is generated through system functioning parameters (reliability): frequency with relative importance $22.0 \%$; staff (drivers) with relative importance $14.0 \%$; headway with relative importance $13.0 \%$. The vehicles features follow: vehicle equipment with relative importance $8.7 \%$, vehicle capacities with $7.0 \%$ and vehicle reliability (technical regularity) with $6.0 \%$;

- finally, based on the absolute importance, the order of elements that should be improved to reach the maximum effects and increase the users' satisfaction level is: vehicle frequency - rank 1, staff (drivers) - rank 2, headway - rank 3, vehicle equipment - rank 4, optimal vehicle capacity - rank 5 and vehicle reliability (technical regularity) - rank 6 .

In other words, the results obtained from QFD application imply that for promoting quality of service improvement and satisfying customer's requirements, the public transport service providers and managers in Belgrade should focus primarily on the service reliability and vehicle elements.

The paper presents the first stage of QFD method as the most critical process part. Result of this stage is reflected through users' requests and their importance as well as transport service key features. These features are 
essential for required service level production and lead to higher users' satisfaction and market advantages generation. Further research should include implementation of other three stages of QFD method.

There are several more further research opportunities related mainly to the users' structure. Needs, expectations and level of quality of service delivered to disabled and elderly people are not subject of this study. Disabled and elderly people's needs and expectations differentiate in various ways (Kurtulmuşoğlu et al. 2016). Another opportunity for further research is to include the perceptions of passengers with different purpose of travel. Heterogeneity between users' requests towards different public transport modes (bus, tram and trolleybus) might be another further research opportunity.

\section{References}

Agarwal, R. 2008. Public transportation and customer satisfaction: the case of Indian railways, Global Business Review 9(2): 257-272.

Apparao, K. C.; Birru, A. K. 2014. Enhancement of customer satisfaction by QFD in metro-taxi service, in Advance Research and Innovations in Mechanical, Material Science, Industrial Engineering and Management - ICARMMIEM-2014, 6-7 January 2014, Warangal, India, 202-205.

Beirão, G.; Cabral, J. A. S. 2007. Understanding attitudes towards public transport and private car: a qualitative study, Transport Policy 14(6): 478-489. https://doi.org/10.1016/j.tranpol.2007.04.009

Chan, L. K.; Wu, M. L. 1998. Prioritizing the technical measures in quality function deployment, Quality Engineering 10(3): 467-479. https://doi.org/10.1080/08982119808919160

Cirillo, C.; Eboli, L.; Mazzulla, G. 2011. On the asymmetric user perception of transit service quality, International Journal of Sustainable Transportation 5(4): 216-232.

https://doi.org/10.1080/15568318.2010.494231

Crosby, P. B. 1991. Quality management in emerging nations, Productivity 32(3): 415-420.

Dale, G. B.; Lascelles, M. D. 1990. The use of quality management techniques, Quality Forum Journal 16(14): 188-192.

Duru, O.; Huang S. T.; Bulut, E.; Yoshida, S. 2013. Multi-layer quality function deployment (QFD) approach for improving the compromised quality satisfaction under the agency problem: a 3D QFD design for the asset selection problem in the shipping industry, Quality \& Quantity 47(4): 2259-2280. https://doi.org/10.1007/s11135-011-9653-4

Eboli, L.; Mazzulla, G. 2012. Structural equation modelling for analysing passengers' perceptions about railway services, Procedia - Social and Behavioral Sciences 54: 96-106. https://doi.org/10.1016/j.sbspro.2012.09.729

Eboli, L.; Mazzulla, G. 2010. How to capture the passengers' point of view on a transit service through rating and choice options, Transport Reviews 30(4): 435-450.

https://doi.org/10.1080/01441640903068441

Eboli, L.; Mazzulla, G. 2007. Service quality attributes affecting customer satisfaction for bus transit, Journal of Public Transportation 10(3): 21-34. https://doi.org/10.5038/2375-0901.10.3.2

Feigenbaum, A. V. 1988. Total quality developments into the 1990s - an international perspective, in R. L. Chase (Ed.). Total Quality Management: an IFS Executive Briefing. Springer.
Filipović, S. 1996. Parametri kvaliteta usluge u sistemu javnog gradskog transporta putnika, in 5. Međunarodni simpozijum SymOrg'96: Menadžment i razvoj preduzeća, 3-5 jun 1996, Vrnjačka Banja, Srbija (in Serbian).

Filipović, S.; Stanković, R. 1996. Standardi i upravljanje kvalitetom usluge u transportu putnika u gradovima, in Prvi međunarodni simpozijum "Industrijsko inženjerstvo'96""SIE'96", 7-9 novembar 1996, Beograd, Srbija, 196-198. (in Serbian).

Filipović, S; Gavrilović, S.; Tica, S. 2002. Istraživanje karakteristika transportnih zahteva, transportne ponude, efikasnosti $i$ kvaliteta sistema javnog masovnog transporta putnika u Beogradu. Univerzitet u Beogradu - Saobraćajni fakultet, Beograd, Srbija (in Serbian).

Filipović, S.; Tica, S.; Živanović, P.; Milovanović, B. 2009. Comparative analysis of the basic features of the expected and perceived quality of mass passenger public transport service in Belgrade, Transport 24(4): 265-273.

https://doi.org/10.3846/1648-4142.2009.24.265-273

Filipović, S.; Živanović, P.; Gavrilović, S.; Milovanović, B. 2006. Istraživanje parametara kvaliteta prevozne usluge za 2005. godinu. Univerzitet u Beogradu - Saobraćajni fakultet, Beograd, Srbija. 127 p. (in Serbian).

Filipović, S.; Živanović, P.; Gavrilović, S.; Milovanović, B. 2007. Istraživanje parametara kvaliteta prevozne usluge za 2006. godinu. Univerzitet u Beogradu - Saobraćajni fakultet, Beograd, Srbija. 155 p. (in Serbian).

Filipović, S.; Živanović, P.; Gavrilović, S.; Milovanović, B. 2008. Istraživanje parametara kvaliteta prevozne usluge za 2007. godinu. Univerzitet u Beogradu - Saobraćajni fakultet, Beograd, Srbija. 238 p. (in Serbian).

Franceschini, F; Rafele, C. 2000. Quality evaluation in logistic services, International Journal of Agile Management Systems 2(1): 49-54. https://doi.org/10.1108/14654650010312589

Friman, M.; Edvardsson, B. 2003. A content analysis of complaints and compliments, Managing Service Quality: an International Journal 13(1): 20-26.

https://doi.org/10.1108/09604520310456681

Greene, R. T. 1993. Global Quality: a Synthesis of the World's Best Management Methods. McGraw-Hill Companies. 886 p.

Grujičić, D.; Ivanović, I.; Jović, J.; Đorić, V. 2014. Customer perception of service quality in public transport, Transport 29(3): 285-295. https://doi.org/10.3846/16484142.2014.951685

GSP 'Beograd'. 2014. Istraživanje parametara kvaliteta prevozne usluge u Beogradu - 2014. Gradsko saobraćajno preduzeće (GSP) 'Beograd', Beograd, Srbija. 58 p. (in Serbian).

Heleta, M. 2010. TQM modeli izvrsnosti $i$ integrisani menadžment sistemi. Zavod za udžbenike Beograd. 639 p. (in Serbian).

Hensher, D. A.; Stopher, P.; Bullock, P. 2003. Service quality: developing a service quality index in the provision of commercial bus contracts, Transportation Research Part A: Policy and Practice 37(6): 499-517. https://doi.org/10.1016/S0965-8564(02)00075-7

Hu, K.-C.; Jen, W. 2006. Passengers' perceived service quality of city buses in Taipei: scale development and measurement, Transport Reviews 26(5): 645-662. https://doi.org/10.1080/01441640600679482

Huang, S. T.; Bulut, E.; Duru, O. 2015. Service quality assessment in liner shipping industry: an empirical study on Asian shipping case, International Journal of Shipping and Transport Logistics 7(2): 221-242. https://doi.org/10.1504/IJSTL.2015.067852

Ivancevich, J. M.; Lorenzi, P.; Skinner, S. J.; Crosby, P. B. 1996. Management: Quality and Competitiveness. 2nd edition. Richard D Irwin. $656 \mathrm{p}$. 
Jayaram, J.; Handfield, R.; Ghosh, S. 1997. The application of quality tools in achieving quality attributes and strategies, Quality Management Journal 5(1): 75-100.

Juran, J. M. 2003. Juran on Leadership for Quality. Free Press. $384 \mathrm{p}$.

Juran, J. M.; Gryna, F. M. 1988. Juran's Quality Control Handbook. 4th edition. McGraw-Hill. 1774 p.

Kurtulmuşoğlu, F. B.; Pakdil, F.; Atalay, K. D. 2016. Quality improvement strategies of highway bus service based on a fuzzy quality function deployment approach, Transportmetrica A: Transport Science 12(2): 175-202.

https://doi.org/10.1080/23249935.2015.1117535

Lim, P. C.; Tang, N. K. H.; Jackson, P. M. 1999. An innovative framework for health care performance measurement, Managing Service Quality: an International Journal 9(6): 423-433. https://doi.org/10.1108/09604529910304125

Maritan, D. 2015. Practical Manual of Quality Function Deployment. Springer International Publishing. 190 p. https://doi.org/10.1007/978-3-319-08521-0

Masing, W. 1988. Handbuch der Qualitätssicherung. Carl HanserVerlag. 1009 s. (in German).

Mizuno, S.; Akao, Y. 1994. QFD: the Customer-Driven Approach to Quality Planning and Deployment. Asian Productivity Organization. $365 \mathrm{p}$.

Pakdil, F.; Kurtulmuşoğlu, F. B. 2014. Improving service quality in highway passenger transportation: a case study using quality function deployment, European Journal of Transport and Infrastructure Research 14(4): 375-393.

Parasuraman, A.; Zeithaml, V. A.; Berry, L. L. 1988. SERVQUAL: a multiple-item scale for measuring consumer perceptions of service quality, Journal of Retailing 64(1): 12-40.

Prasad, B. 1998. Review of QFD and related deployment techniques, Journal of Manufacturing Systems 17(3): 221-234. https://doi.org/10.1016/S0278-6125(98)80063-0

Radivojević, G.; Miljuš, M.; Vidović, M. 2007. Logistički kontroling $i$ performanse. Univerzitet u Beogradu - Saobraćajni fakultet, Beograd, Srbija. 229 p. (in Serbian).

Rao, K. C. A.; Thakar, G. 2013. Enhancement of customer satisfaction by QFD in bus service, International Journal on Advanced Computer Theory and Engineering 2(5): 1-6.

Shieh, J.-I.; Wu, H.-H. 2009. Applying a hidden Markov chain model in quality function deployment to analyze dynamic customer requirements, Quality \& Quantity 43(4): 635-644. https://doi.org/10.1007/s11135-007-9153-8

Spasojević, V. 1999. Uticaj tehničkih faktora na izbor alata za poboljšanje kvaliteta: Ms Thesis. Univerzitet u Beogradu Mašinski fakultet, Beograd, Srbija. 151 p. (in Serbian).

Stoiljković, V.; Uzunović, R.; Majstorović, V. 1996. Alati kvaliteta. Mašinski fakultet Niš - CIM College, Srbija. 134 p. (in Serbian).

Stradling, S.; Carreno, M.; Rye, T.; Noble, A. 2007. Passenger perceptions and the ideal urban bus journey experience, Transport Policy 14(4): 283-292.

https://doi.org/10.1016/j.tranpol.2007.02.003

Tica, S. 2011. Prilog razvoju metoda za strateško upravljanje sistemom javnog gradskog transporta putnika: $\mathrm{PhD}$ Thesis, Univerzitet u Beogradu - Saobraćajni fakultet, Beograd, Srbija. 209 p. (in Serbian).

Tica, S. 2001. Prilog razvoju metoda za upravljanje sistemima javnog masovnog transporta putnika: Ms Thesis. Univerzitet u Beogradu - Saobraćajni fakultet, Beograd, Srbija. 160 p. (in Serbian).
Tyrinopoulos, Y.; Antoniou, C. 2008. Public transit user satisfaction: variability and policy implications, Transport Policy 15(4): 260-272.

https://doi.org/10.1016/j.tranpol.2008.06.002

$\mathrm{Wu}$, H.-H. 2006. Applying grey model to prioritise technical measures in quality function deployment, The International Journal of Advanced Manufacturing Technology 29(11-12): 1278-1283. https://doi.org/10.1007/s00170-005-0016-y

Wu, H.-H.; Liao, A. Y. H.; Wang, P.-C. 2005. Using grey theory in quality function deployment to analyse dynamic customer requirements, The International Journal of Advanced Manufacturing Technology 25(11-12): 1241-1247. https://doi.org/10.1007/s00170-003-1948-8

Wu, H.-H.; Shieh, J.-I. 2010. Applying repertory grids technique for knowledge elicitation in quality function deployment, Quality \& Quantity 44(6): 1139-1149. https://doi.org/10.1007/s11135-009-9267-2

Zeithaml, V. A.; Berry, L. L.; Parasuraman, A. 1996. The behavioral consequences of service quality, Journal of Marketing 60(2): 31-46. https://doi.org/10.2307/1251929 